\title{
Rancang Bangun Sistem Informasi Administrasi Jasa Penitipan Hewan Berbasis Web
}

\author{
Hesti Rian $^{\left.1)^{*}\right)}$, Jidan Altama Nugraha ${ }^{2)}$ \\ ${ }^{12)}$ Program Studi Manajemen Informatika, Politeknik LP3I Jakarta \\ ${ }^{*}$ Correspondence Author: hestiriangustiawan@gmail.com, Jakarta, Indonesia
}

DOI: https://doi.org/10.37012/jtik.v7i2.645

\begin{abstract}
Abstrak
Pengembangan Sistem Informasi Administrasi Jasa Penitipan Hewan ini merupakan suatu sistem input data Pemilik, Kucing, Jenis Paket. Sistem input data Pemilik meliputi Nama Pemilik, Alamat, dan No Telepon. Sistem input kucing meliputi Nama Kucing, Jenis Kelamin, Keterangan, Berat, dan Rekomendasi Dokter Hewan. Sistem input Jenis Paket meliputi, Jenis Paket, Harga, dan Keterangan Paket. Tujuan sistem Administrasi Jasa Penitipan Hewan adalah untuk mempermudah pengelola data Administrasi Jasa Penitipan Hewan dalam mengelompokkan data dan membuat laporan berkala dan juga mempermudah pemilik hewan mendapat kemudahan dalam mengakses info tempat penitipan hewan yang dengan mudah dapat diakses melalui media website. Pengembangan sistem ini menggunakan metode siklus daur hidup pengembangan sistem. Metode tersebut meliputi beberapa tahapan proses yaitu tahap perencanaan sistem, tahap analisis sistem, tahap perancangan sistem, tahap penerapan sistem, tahap evaluasi sistem, tahap penggunaan dan pemeliharan sistem. Sistem Informasi Administrasi Jasa Penitipan Hewan diharapkan dapat mempermudah proses pembuatan laporan Petugas sehingga dapat menghasilkan data yang akurat dan efektif dan juga mempermudah pemilik hewan untuk menemukan informasi dengan cepat untuk tempat penitipan hewan.
\end{abstract}

Kata Kunci : sistem, informasi, penitipan.

\begin{abstract}
The development of the Animal Care Service Administration Information System is a data input system for Owners, Cats, Types of Packages. Owner data input system includes Owner's Name, Address, and Telephone Number. The cat input system includes Cat Name, Gender, Description, Weight, and Veterinarian Recommendation. The Package Type input system includes Package Type, Price, and Package Description. The purpose of the Veterinary Service Administration system is to make it easier for data managers of the Animal Care Service Administration to classify data and make periodic reports and also make it easier for animal owners to have easy access to information on animal care which can be easily accessed through the media website. The development of this system uses the system development life cycle method. The method includes several stages of the process, namely the system planning stage, the system analysis stage, the system design stage, the system implementation stage, the system evaluation stage, the system use and maintenance stage. The Animal Care Service Administration Information System is expected to facilitate the process of making officer reports so that they can produce accurate and effective data.
\end{abstract}

Keywords : systems, information, care.

\section{PENDAHULUAN}

Adanya kekhawatiran terhadap hewan ketika ditinggal pergi oleh pemiliknya membuat pemilik menitipkan hewan peliharaannya ke penitipan hewan yang terpercaya dan menjamin perawatan selama dititipkan. Tidak banyak penitipan hewan yang memberikan layanan yang baik terhadap 
pelanggan maupun hewan yang dititipkan. Layanan yang baik adalah layanan yang memenuhi kebutuhan pelanggan. Layanan yang sedang berjalan saat ini di penitipan hewan masih belum memberikan informasi yang lengkap terhadap kebutuhan konsumen dimana salah satu faktor yang menyebabkan menurunnya kualitas layanan dan kepuasan pelanggan terhadap penitipan hewan tersebut. Permasalahan yang ada karena tidak digunakannya teknologi informasi dengan baik dalam memberikan informasi. Diperlukan adanya media penyajian data dengan dukungan teknologi informasi berupa web untuk melakukan pendaftaran dengan mudah, akses cepat untuk mendapatkan informasi yang lengkap mengenai aktivitas dan kondisi dari hewan selama dititipkan di penitipan hewan tersebut. Dengan adanya sebuah sistem informasi berbasis web dalam mengolah data layanan penitipan hewan ini akan mempermudah pihak penitpan hewan dan pelanggan untuk mendapatkan informasi dengan lebih cepat dan tepat. Dengan itu dapat meningkatkan kualitas pelayanan penitipan serta kepuasan konsumen.

\section{METODE}

Metode penelitian yang digunakan dalam membuat system informasi ini adalah waterfall, melalui tahapan sebagai berikut:

\section{Analisis}

\section{Desain Sistem}

\section{Pengkodean}

\section{Pengujian}

\section{Implementasi}

Use case merupakan sebuah rangkaian/uraian dari kelompok yang saling terkait dan membentuk sistem yang teratur yang dilakukan atau diawasi oleh aktor. Use case berfungsi untuk membentuk tingkah laku benda dalam sebuah mode dan direalisasikan oleh sebuah collaborator, umumnya use case digambarkan melalui sebuah elips dengan garis yang solid, biasanya mengandung nama.[10]

Class diagram merupakan diagram yang digunakan untuk pengembangan perangkat lunak berorientasi User Sistem Mengetik User dan Password start Mengklik tombol login Memeriksa Status Login Membelikan Halaman Dashboard yes no end 15 objek yang menggambarkan perilaku dan terdiri dari kumpulan class dan relasinya.[8]

Database merupakan suatu kumpulan data yang berhubungan secara logis dan deskripsi data tersebut, yang dirancang untuk memenuhi informasi yang dibutuhkan oleh suatu organisasi.[3]. Interface atau antar muka adalah salah satu bagian dalam pembangunan sebuah aplikasi. Terlebih aplikasi tersebut merupakan aplikasi yang kerap diakses oleh banyak 
pengguna.[12]. PHP merupakan bahasa server-side scripting yang memiliki kesatuan dengan HTML untuk membangun halaman web yang dinamis. PHP (Hypertext Preprocessor) merupakan bahasa pemrograman script untuk membuat aplikasi web dimana membutuhkan website server dalam menjalankan aksinya.[1]. CodeIgniter merupakan framework web untuk bahasa pemrograman PHP yang dibuat Rick Ellis tahun 2006, yaitu penemu dan pendiri EllisLab.[11].

\section{HASIL DAN PEMBAHASAN}

Analisa kebutuhan software dengan prosedur seperti :

Halaman Admin :

a. Admin dapat melakukan login

b. Admin dapat mengelola data pemilik

c. Admin dapat mengelola data kucing

d. Admin dapat mengelola data jenis paket

e. Admin dapat mengelola data pendaftaran

f. Admin dapat mengelola data pemantauan

g. Admin dapat mengelola data pengembalian

h. Admin dapat mengelola data laporan

\section{Halaman Pemeriksa :}

a. Pemeriksa dapat melakukan login

b. Pemeriksa dapat mengelola data pemantauan

Halaman Pimpinan :

a. Pimpinan dapat melakukan login

b. Pimpinan dapat mengelola data laporan

Deskripsi prosedur analisis sistem :

Konsumen datang membawa kucing peliharaan, konsumen diajak untuk melihat tempat penginapan, konsumen akan mengisi formulir lalu memilih jenis paket penginapan, Jika kucing sakit, pemilik harus memberikan surat dokter hewan, lalu konsumen akan melakukan pembayaran ke pihak administrasi, admin akan mengisi kartu pantau yang isinya sesuai dengan formulir, kartu pantau akan ditempel ditempat penginapan kamar kucing. Admin akan membuat kwitansi sebanyak 2 rangkap, kwitansi rangkap 1 untuk admin dan 
kwitansi rangkap 2 untuk konsumen, kucing akan dipantau setiap harinya sesuai dengan lama menginap oleh pemeriksa. Kucing akan diberikan makanan basah satu hari sekali dan diberikan makanan kering, jika makanan kering habis akan diisi ulang, kucing akan dimandikan jika menginap selama 3 hari atau lebih. Jika kucing yang dititipkan dalam kondisi sehat lalu sakit, pemeriksa akan membawa kucing ke dokter hewan terdekat dan biaya obat akan ditanggung oleh konsumen, konsumen diharuskan membawa kwitansi rangkap 2 yang dibentuk di awal. Jika pengembalian lewat dari jam 12 siang maka biaya menginap ditambah satu hari.

Desain sistem usulan digambarkan seperti usecase diagram di bawah ini :

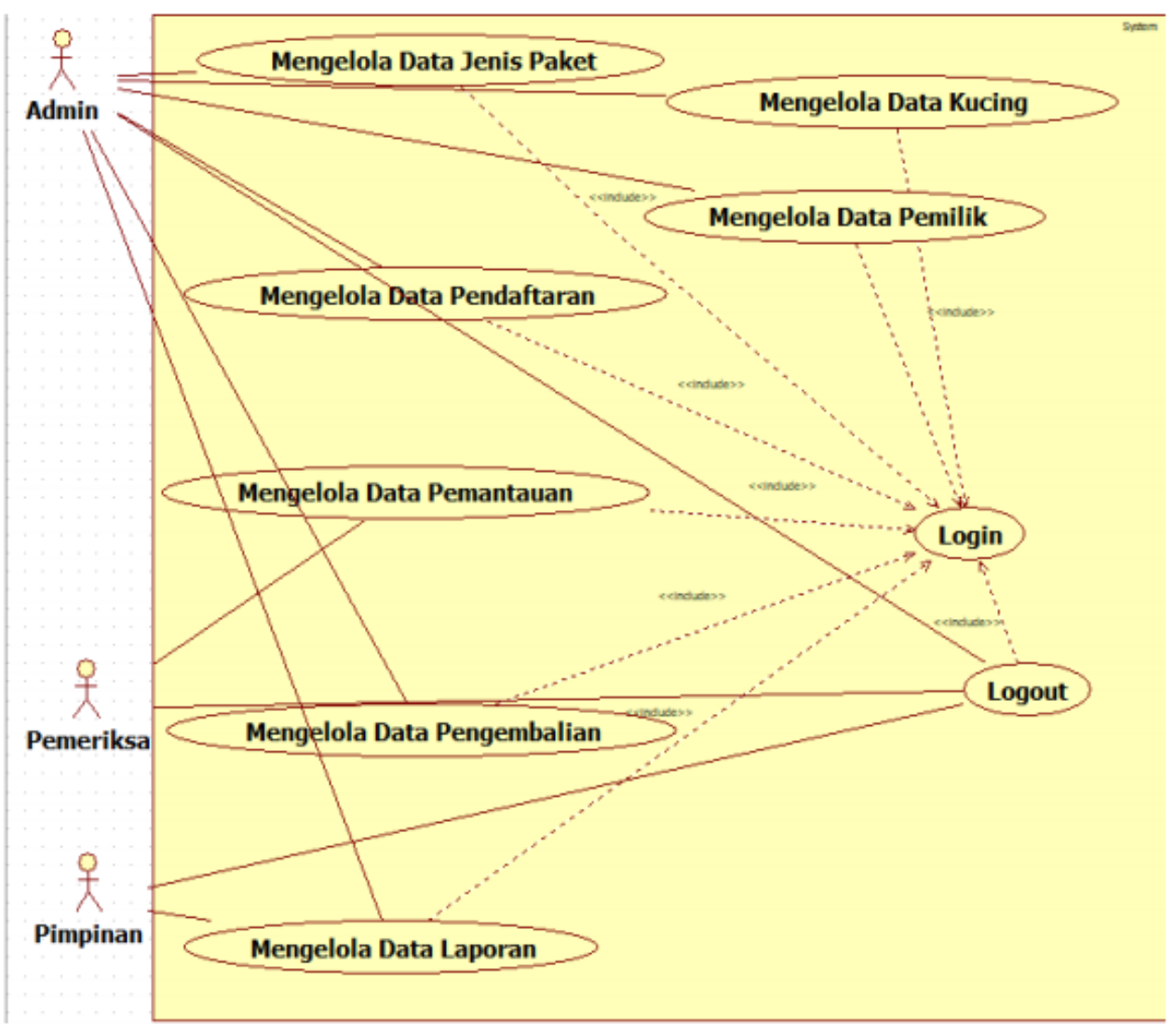

Gambar 1. Use Case Diagram 


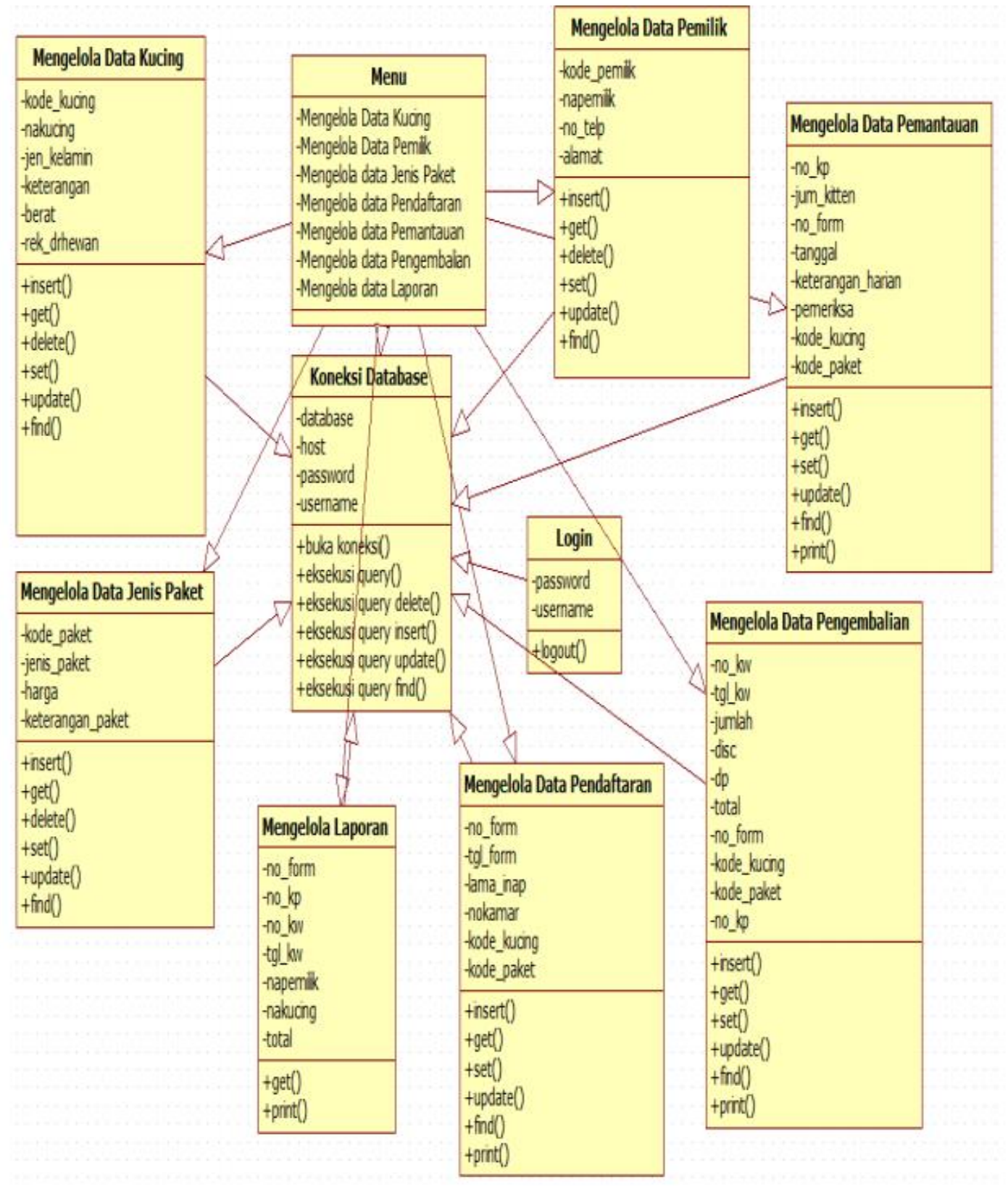

Gambar 2. Class Diagram 


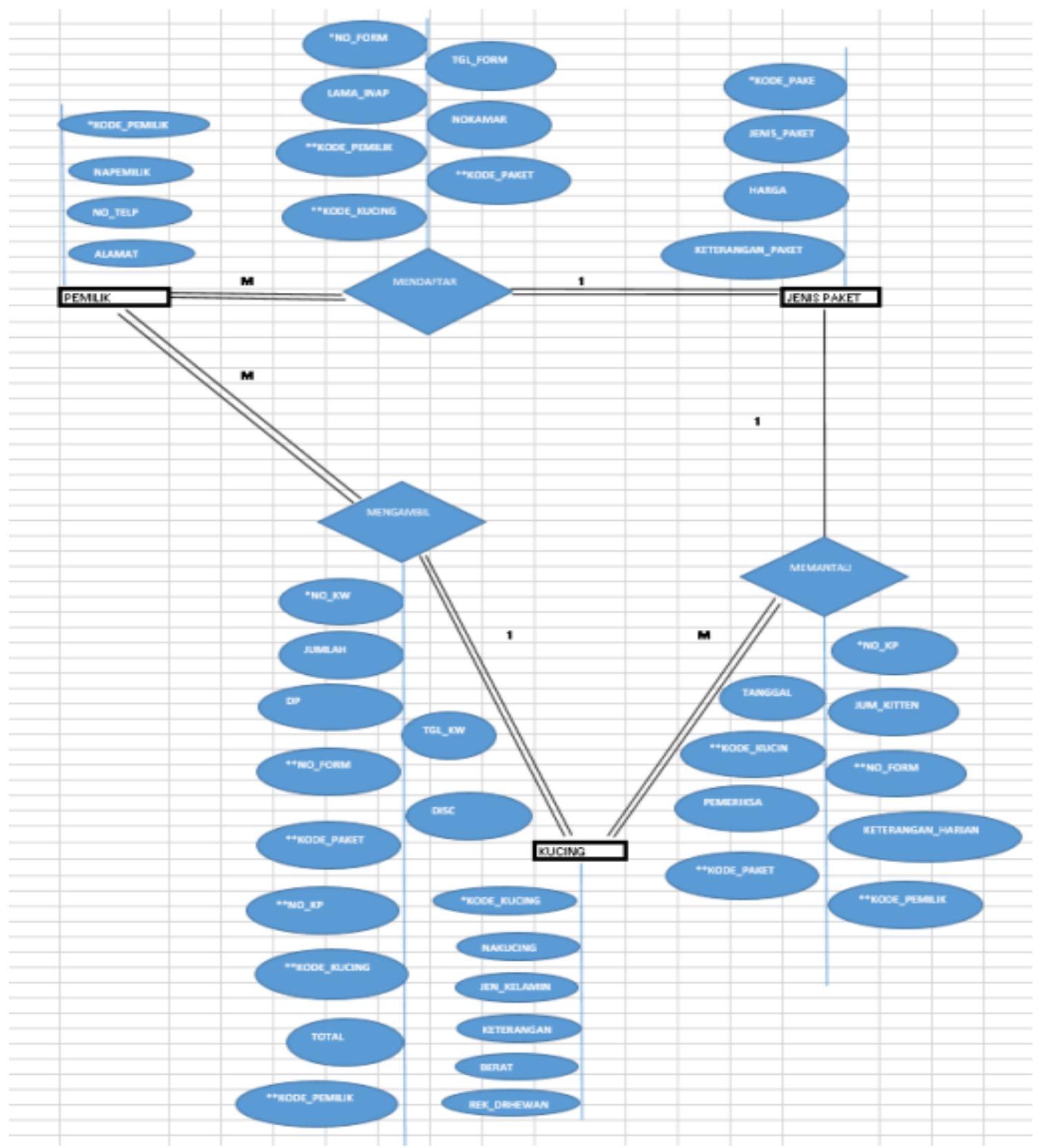

Gambar 3. Entity Relational Diagram 


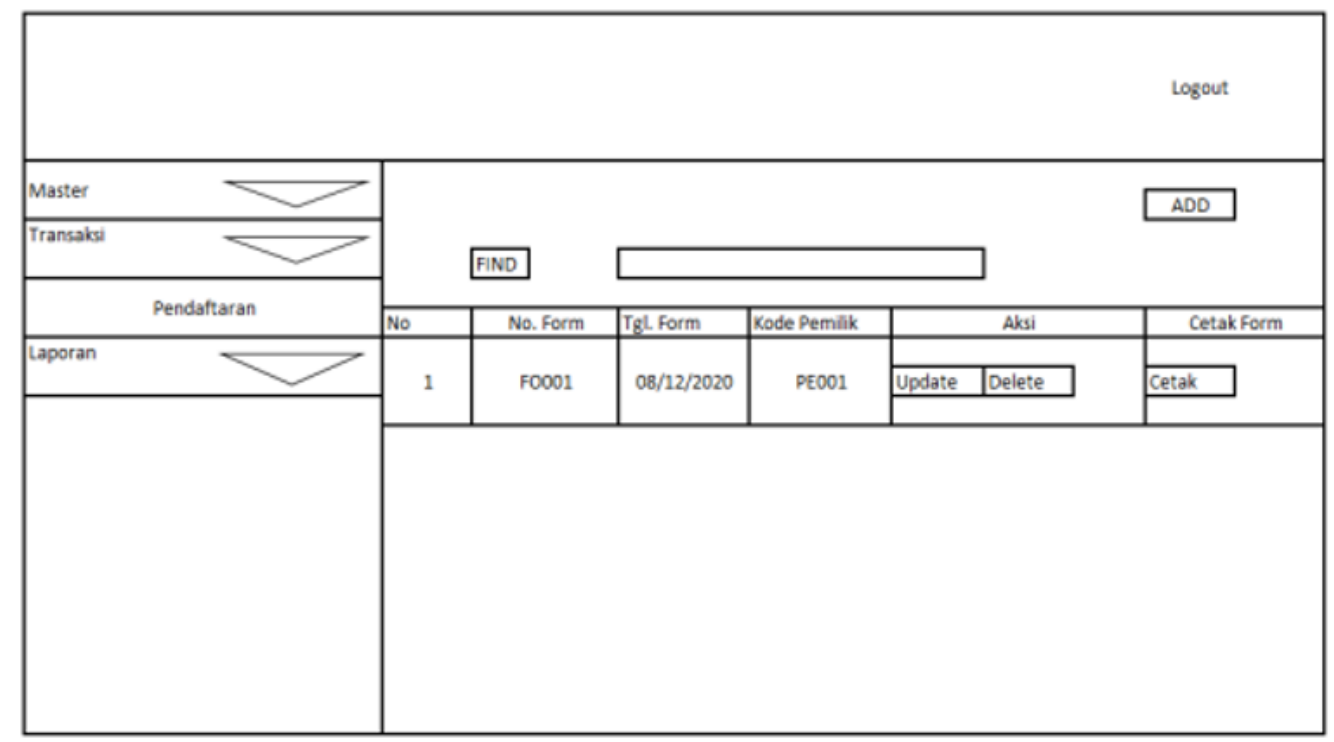

Gambar 4. Perancangan User Interface Form Pendaftaran

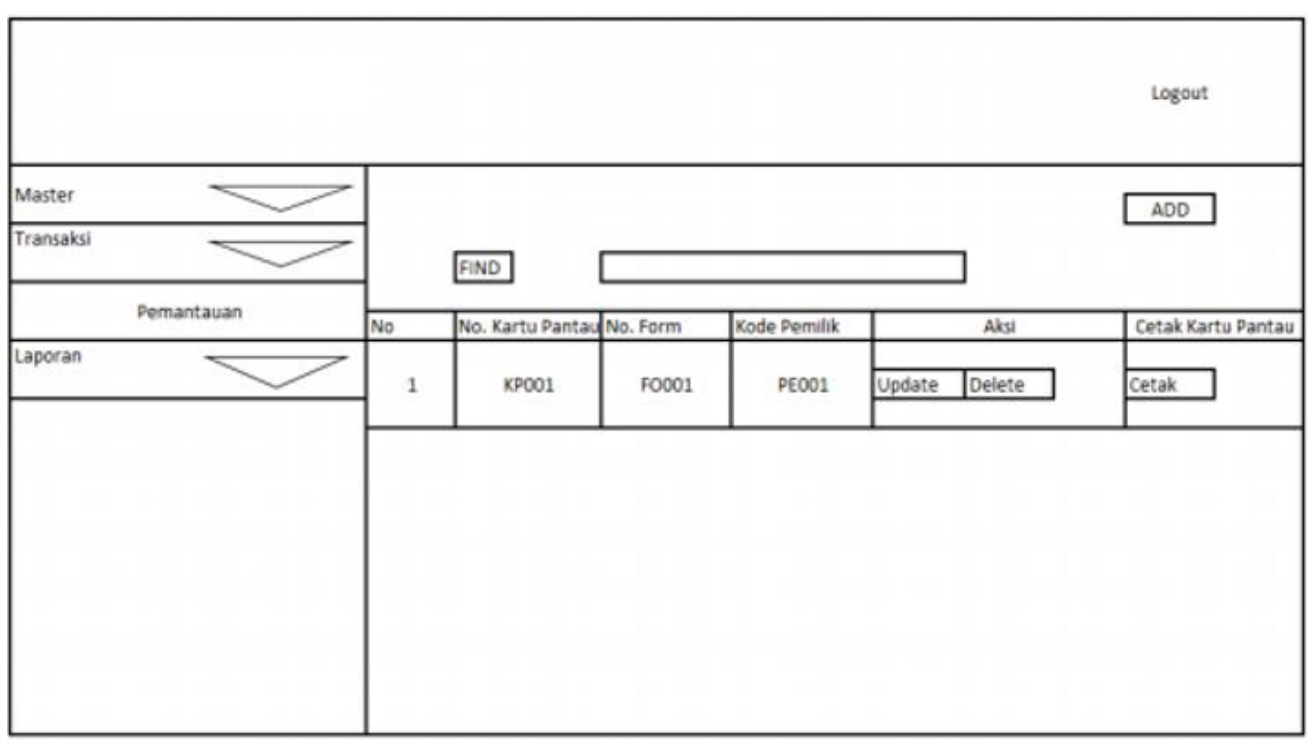

Gambar 5. Perancangan User Interface Form Pemantauan 


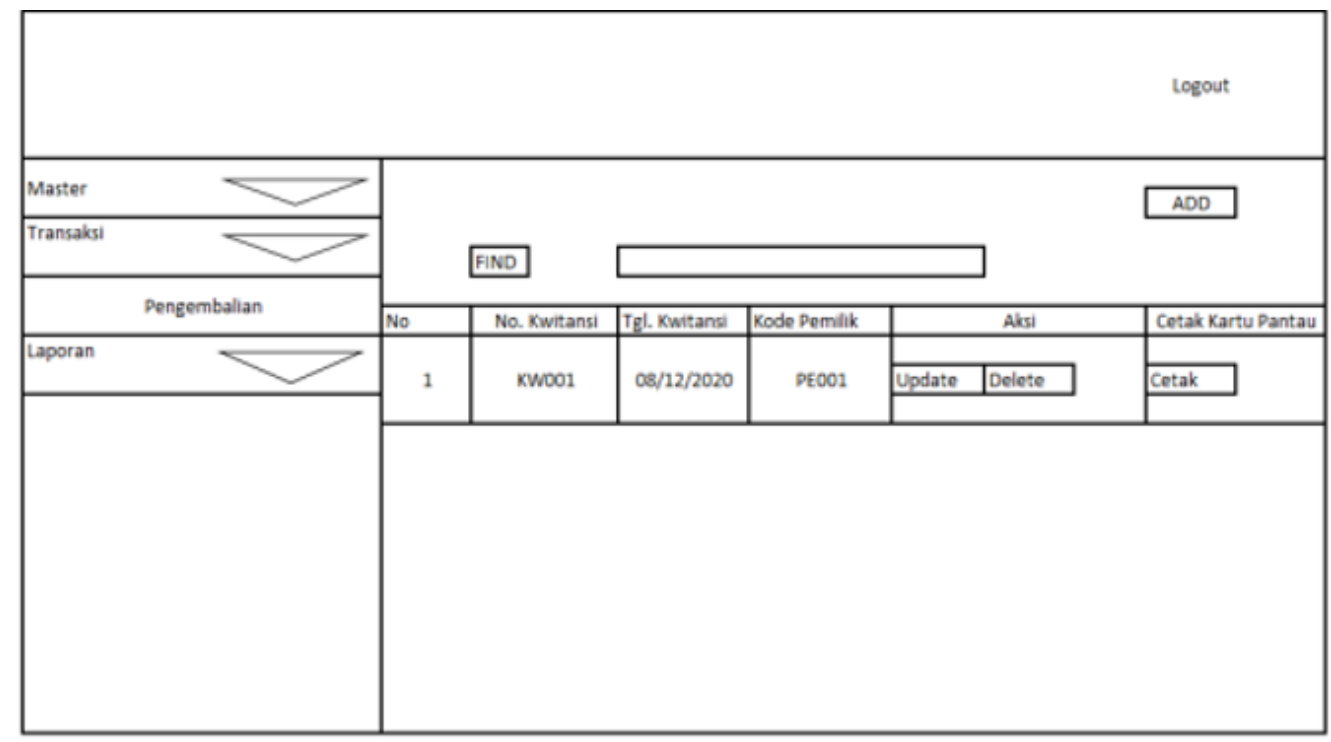

Gambar 6. Perancangan User Interface Form Pengembalian

\section{Kebutuhan Infrastruktur :}

1. Sistem Operasi

Windows 10

\section{Kebutuhan Hardware}

a) Type Laptop : ACER Predator Helios 300 G3-572

b) Processor : Intel Core i7

c) RAM : $16.00 \mathrm{~GB}$

3. Jaringan Komputer

Xampp

4. Kebutuhan Software
a. Tools Editor
: Atom, Notepad++
b. Web Browser
: Google Chrome
c. Web server
: Xampp
d. Database
: Mysql
e. Program
: PHP

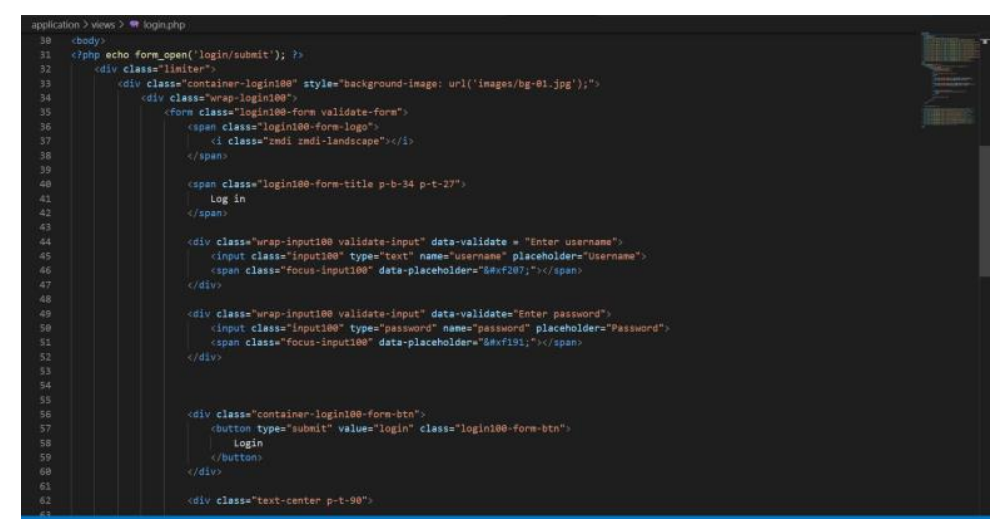

Gambar 7. Pengkodean Login 


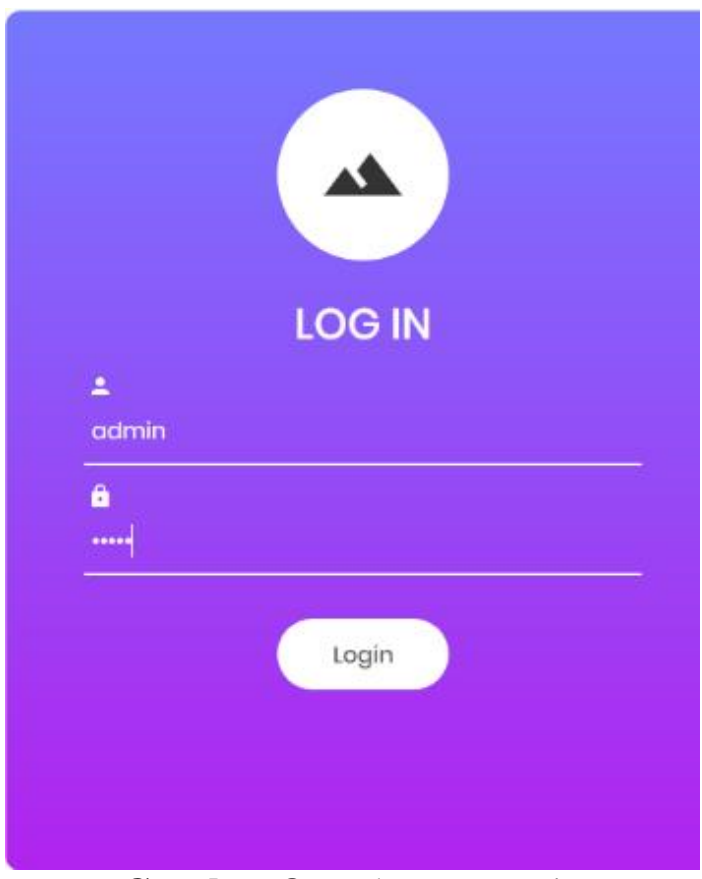

Gambar 8. Halaman Login

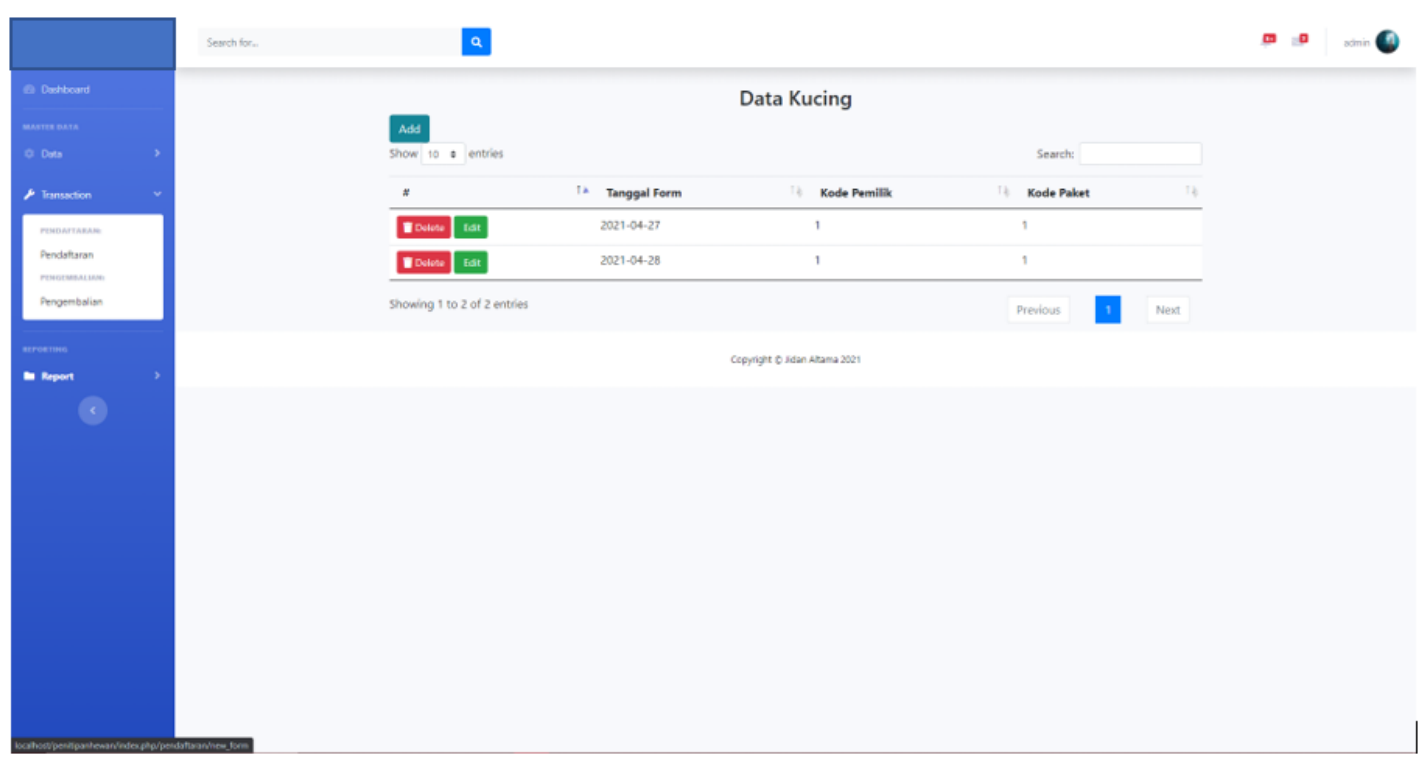

Gambar 9. Halaman List Pendaftaran 


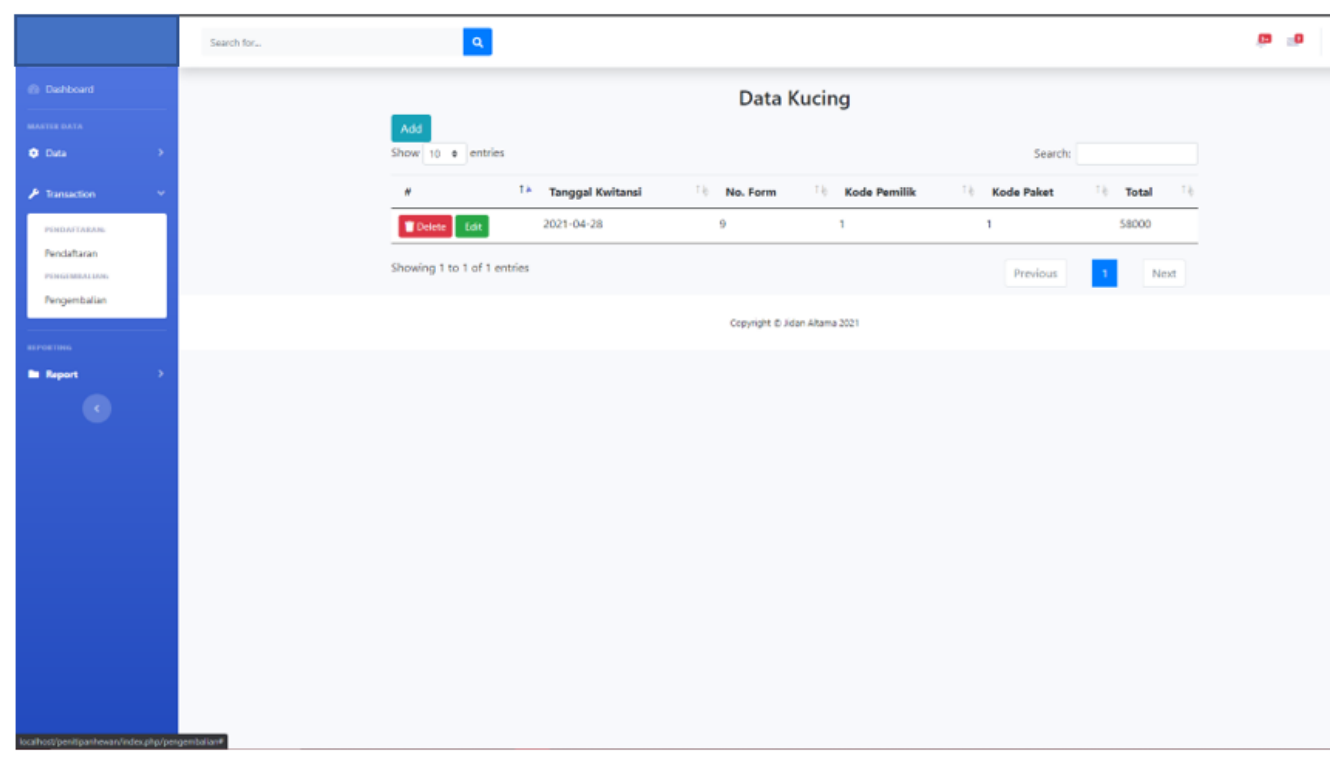

Gambar 10. Halaman List Pengembalian

Tabel 1. Hasil Pengujian Black Box Testing Form Login Admin

\begin{tabular}{|c|c|c|c|c|c|}
\hline No. & $\begin{array}{l}\text { Fungsi Yang } \\
\text { Diuji }\end{array}$ & Kondisi & Hasil Yang Diharapkan & $\begin{array}{l}\text { Hasil } \\
\text { Pengujian }\end{array}$ & Kesimpulan \\
\hline 1 & Login & $\begin{array}{l}\text { Username dan } \\
\text { Password } \\
\text { kosong }\end{array}$ & $\begin{array}{l}\text { Sistem menolak akses } \\
\text { login lalu menampilkan } \\
\text { pesan "silahkan isi } \\
\text { username/password" }\end{array}$ & Sesuai & Valid \\
\hline 2 & Login & $\begin{array}{l}\text { Username dan } \\
\text { Password benar }\end{array}$ & $\begin{array}{l}\text { Sistem menerima akses } \\
\text { login lalu masuk ke } \\
\text { halaman dashboard }\end{array}$ & Sesuai & Valid \\
\hline 3 & Login & Username salah & $\begin{array}{l}\text { Sistem menolak akses } \\
\text { login lalu menampilkan } \\
\text { pesan "Login tidak } \\
\text { valid" }\end{array}$ & Sesuai & Valid \\
\hline 4 & Login & $\begin{array}{l}\text { Username benar } \\
\text { dan password } \\
\text { salah }\end{array}$ & $\begin{array}{l}\text { Sistem menolak akses } \\
\text { login lalu menampilkan } \\
\text { pesan "Password salah" }\end{array}$ & Sesuai & Valid \\
\hline
\end{tabular}

\section{KESIMPULAN DAN REKOMENDASI}

Pencatatan data yang masih manual dalam memonitoring proses administrasi menyebabkan data menjadi tidak rapih dan banyak yang terselip dan hilang sehingga sulit untuk memonitoring perkembangan administrasi setiap harinya. Adanya perancangan sistem ini akan memudahkan petugas dalam melakukan proses pencatatan data administrasi jasa penitipan hewan mulai dari pendaftaran, pemantauan dan pengembalian hewan. 


\section{REFERENSI}

Agustino, R., Widodo, Y. B., Wiyatno, A., \& Saputro, M. I. (2020). Sistem Informasi Penelitian dan Pengabdian Masyarakat di Universitas Mohammad Husni Thamrin. Jurnal Jaring SainTek, 2(1), 1-12.

Dzulhaq, M.Iqbal, Rahmat Tullah dan Putra Satia Nugraha, 2017. Sistem Informasi Akademik Sekolah Berbasis Kurikulum 2013. Jurnal Sisfotek Global. Vol. 7 No. 1

Efendy, Zainul. 2018. Normalisasi Dalam Desain Database. Jurnal CoreIT. Vol.4 No. 1, Juni 2018

Indrajani. 2018. Database System All in One: Theory, Practice, and Case Study. Jakarta: PT Elex Media Komputindo.

Kurniawan, Tri A. 2018. Pemodelan Use Case (UMl): Evaluasi Terhadap Beberapa Kesalahan dalam Praktik. Jurnal Teknologi Informasi dan Ilmu Komputer. Vol.5, No. 1, Maret 2018

Maimunah, David Ericson Manalu dan Dian Budi Kusuma. 2017. Perancangan Prototype Visual pada Bagian Desain Sebagai Media Informasi dan Promosi pada PT Sulindafin.Yogyakarta: Jurnal Semnasteknomedia Universitas Amikom Yogyakarta. Vol. 5 number 1, Februari 2017.

Meilinda, E. 2016. Perancangan Aplikasi Kearsipan Surat Menyurat Pada Badan Pemerintahan (Studi Kasus: Badan Pemberdayaan Perempuan Perlindungan Anak Dan Keluarga Berencana Pontianak). Jurnal Khatulistiwa Informatika. Vol.4 No.2

Mokhammad Ridoi, S. S. 2018. Cara Mudah Membuat Game Edukasi dengan Construct 2: Tutorial sederhana Construct 2. Jakarta: Maskha

Mulyani, Sri. 2016. Sistem Informasi Management Rumah Sakit : Analisis Dan Perancangan. Bandung: Abdi Sistematika.

Nadeak, Berto. Abbas Parulian. Pristiwanto dan Saidi Ramadan Siregar. 2016. Perancangan aplikasi pembelajaran internet dengan menggunakan metode computer based instruction. Medan: STMIK Budi Darma Journal Riset Komputer (JURIKOM). ISSN 2407-389X. Vol. 3, No. 4 : 54.

Rahardi, Majid dkk. 2016. Perancangan Sistem Group Tracking Pada Aktivitas Touring Berbasis Mobile. Seminar Nasional Teknologi Informasi dan Mulitimedia 2016 Vol. 4 No. 1 
Raharjo, Budi. 2016. Pemrograman GUI dengan C++ dan Qt. Bandung: Informatika Bandung.

Safaat, Nazruddin h. 2015. Pemrograman Aplikasi Mobile Smartphone dan Tablet PC berbasis android, Cetakan Pertama, Edisi Revisi, Bandung: Penerbit Informatika Bandung.

Suprapto, Falahah. 2018. Rekayasa Perangkat Lunak. Jakarta: Lentera Ilmu Cendekia. Sutabri, Tata. 2016. Sistem Informasi Manajemen (Edisi Revisi). Yogyakarta : Andi. 